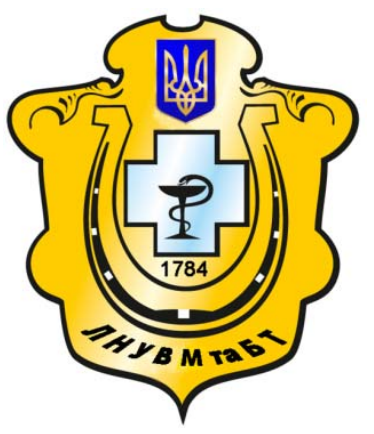

Науковий вісник Львівського національного університету ветеринарної медицини та біотехнологій імені С.3. Гжицького

Scientific Messenger of Lviv National University of Veterinary Medicine and Biotechnologies named after S.Z. Gzhytskyj

doi:10.15421/nvlvet6633

ISSN 2413-5550 print

ISSN 2518-1327 online

$\underline{\text { http://nvlvet.com.ua/ }}$

УДК 615.25: 636.3

\title{
Комплексні препарати на основі нанобіоматеріалів, перспективи використання у репродукції овець та кіз
}

\author{
П.М. Скляров ${ }^{1}$, В.П. Кошевой ${ }^{2}$ \\ skliarov.p.m@dsau.dp.ua, viktor.p.koshevoy@gmail.com \\ ${ }^{1}$ Дніпропетровський державний аграрно-економічний університет, \\ вул. Ворочилова, 25, м. Дніпро, 49600, Україна; \\ Харківська державна зооветеринарна академія, \\ вул. Ювілейна, 1, смт Мала Данилівка, Дергачівський р-н, Харківська обл., 62341, Украӥна,
}

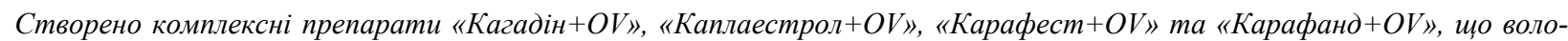
діють антиоксидантними, антигіпоксичними та мембранопротекторними властивостями завдяки вмісту нанобіомате-

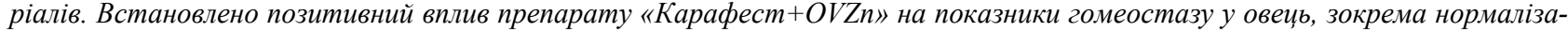
цію вмісту у сироватиі крові вітаміну А, ичику та загального білка; стан прооксидантно-антиоксидантної системи за вмістом у сироватиі крові малонового діальдегіду, каталази, супероксиддисмутази і в еритроцитах - малонового діальдегіду, каталази, відновленого глутатіону та прооксидантно-антиоксидантне співвіднотення; стан системи кисневого метаболізму - кількість еритроцитів та гемоглобіну, кониееттрацію 2,3- дифосфоглічерату.

Так, за використання препарату «Карафест+OVZn» збільшився вміст у сироватці крові: вітаміну А (на 16,2\%), цинку (на 23,4\%), загального білка (на 11,5\%), малонового діальдегіду (на 17,5\%), каталази (на 24,7\%), супероксиддисмутази (на 17,9\%); в еритроцитах: малонового діальдегіду (на 24,4\%), каталази (на 23,9\%) та відновленого глутатіону (на 18,2\%), а також вміст гемоглобіну (на 23,5\%), власне кількість еритроцитів (на 21,8\%), концентрація 2,3-дифосфогліцерату (на 22,2\%) і нормалізувалася прооксидантно-антиоксидантне співвідношення.

Ключові слова: вівиі, кози, репродукиія, комбіновані препарати, нанобіоматеріали, «Карафест+OVZn», фетоплацентарний комплекс, потенціал розвитку новонароджених.
\end{abstract}

\section{Комплексные препараты на основе нанобиоматериалов, перспективы использования в репродукции овец и коз}

\author{
П.Н. Скляров ${ }^{1}$, В.П. Кошевой \\ skliarov.p.m@dsau.dp.ua, viktor.p.koshevoy@gmail.com \\ ${ }^{1}$ Днепропетровский государственный аграрно-экономический университет \\ ул. Ворошилова, 25, г. Днепр, 49600, Украина; \\ ${ }^{2}$ Харьковская государственная зооветеринарная академия, \\ ул. Академическая, 1, пгт Малая Даниловка, Дергачёвский p-н, Харьковская обл., 62341, Украина
}

\begin{abstract}
Созданы комплексные препараты «Кагадин $+O V »$, «Каплаэстрол+OV», «Карафест+OV» и «Карафанд+OV», обладающие антиоксидантными, антигипоксическими и мембранопротекторными свойствами благодаря содержанию нанобиоматериалов. Установлено положстельное влияние препарата «Карафест+OVZn» на показатели гомеостаза у овеи, в частности нормализачию содержания в сыворотке крови витамина А, иинка и общего белка; состояние прооксидантноантиоксидантной системы по содержанию в сыворотке крови - малонового диальдегида, каталазы, супероксиддисмутазы и в эритроцитах - малонового диальдегида, каталазы, восстановленного глутатиона и прооксидантно-антиоксидантное соотношение; состояние системы кислородного метаболизма - количество эритроцитов и гемоглобина, концентрацию 2,3-
\end{abstract}

\section{Citation:}

Sklyarov, P.M., Koshevoy, V.P. (2016). Complex drugs based on nanobiomaterials, future use in the reproduction of sheep and goats. Scientific Messenger LNUVMBT named after S.Z. Gzhytskyj, 18, 2(66), 162-165. 
дифосфоглицерата. Так, при использовании препарата «Карафест+OVZп» увеличилось содержание в сыворотке крови: витамина А (на 16,2\%), цинка (на 23,4\%), общего белка (на 11,5\%), малонового диальдегида (на 17,5\%), каталазь (на 24,7\%), супероксиддисмутазы (на 17,9\%); в эритроцитах: малонового диальдегида (на 24,4\%), каталазы (на 23,9\%) и восстановленного глутатиона (на 18,2\%), а такюе содержание гемоглобина (на 23,5\%), собственно количество эритроцитов (на 21,8\%), концентрация 2,3-дифосфоглицерата (на 22,2\%) и нормализовалась прооксидантно-антиоксидантное соотношение.

Ключевье слова: овцыь, козы, репродукиия, комбинированные препараты, нанобиоматериаль, «Карафест+OVZn», фето-плацентарный комплекс, потенциал развития новорожденных.

\title{
Complex drugs based on nanobiomaterials, future use in the reproduction of sheep and goats
}

\author{
P.M. Sklyarov ${ }^{1}$, V.P. Koshevoy ${ }^{2}$ \\ skliarov.p.m@dsau.dp.ua, viktor.p.koshevoy@gmail.com \\ ${ }^{1}$ Dnipropetrovsk State Agrarian and Economic University, \\ Voroshilov Str., 25, Dnepr, 49600, Ukraine \\ ${ }^{2}$ Kharkiv State Zooveterinary Academy, \\ Akademichna Str., 1, Mala Danylivka, Kharkiv region, Dergachi district, 62341, Ukraine,
}

I.

A complex preparations «Kahadin $+O V »$, KKaplaestrol $+O V »$, «Karafest $+O V »$ and «Karafand $+O V »$, which have antioxidant, anti-hypoxic and membranoprotective properties thanks to nanobiomaterials.

Were tested drug «Karafest $+O V$ Zn», at doses of justification which came out of the daily needs of animals in the components of the drug, which for sheep and goats in the last 7-8 weeks of pregnancy (per animal), carotene $-0.28-0.5 \mathrm{mg} / \mathrm{kg}, \mathrm{or} 12-26 \mathrm{mg}$, phytoestrogens $-0,0175 \mathrm{mg} / \mathrm{kg}$ or $0.61-1.22 \mathrm{mg}$, zinc $-1-1.08 \mathrm{mg} / \mathrm{kg}$, or $54-70 \mathrm{mg}$.

The content of substances in $1 \mathrm{ml}$ «Karafest $+\mathrm{OV} \mathrm{Zn}$ » according to the technical specifications are: carotene - $10 \mathrm{mg}(1,2-$ 2,6 ml), phytoestrogens $-1 \mathrm{mg}(0.6-1.2 \mathrm{ml})$, zinc carbonate $-2 \mathrm{mg}$, ortovanadate europium activated gadolinium $-0.00015 \mathrm{mg}$.

The final dosage was determined by the scheme - $0.35-2.1 \mathrm{ml} /$ animal or 0.01-0.03 ml/kg body weight/day.

The drug «Karafest $+\mathrm{OV} Z n »$ asked orally with food daily for a month to projected pregnancy (140 days of pregnancy).

The positive effect of the drug «Karafest $+O V \mathrm{Zn}$ » at the homeostasis parameters in sheep, including normalization of serum vitamin A, zinc and total protein; prooxidative-antioxidant system containing serum - malondialdehyde, catalase, superoxide dismutase and erythrocyte - malondialdehyde, catalase, restored glutathione and oxidative-antioxidant value; system state oxygen metabolism - the number of red blood cells and hemoglobin concentration of 2.3-dyphosphoglyceratis.

Thus, the use of the drug «Karafest $+\mathrm{OV}$ Zn» increased content in blood serum, vitamin A (by 16.2\%), zinc (by 23,4\%), total protein (by 11.5\%), malondialdehyde (by 17.5\%), catalase (by 24.7\%), superoxide dismutase (by 17.9\%); in erythrocytes: (by $24.4 \%$ ), catalase (by $23.9 \%$ ) and reduced glutathione (by 18.2\%) and hemoglobin (by $23.5 \%$ ), the actual number of red blood cells (by 21.8\%), the concentration of 2,3-dyphosphoglyceratis (by 22.2\%) and normalized prooxidant-antioxidant ratio

Key words: sheep, goats, reproduction, combined preparations, nanobiomaterials «Karafest $+O V Z n »$, feto-placental complex, the potential development of infants newborn.

\section{Вступ}

На сьогодні проводяться інтенсивні дослідження 3 впровадження результатів нано-технологій у практичну діяльність людини. Нанонаука за нетривалий період розвитку знайшла своє застосування у різних напрямках (Glazko, 2010; Chekman, 2011; Eifler and Thaxton, 2011). У медицині гуманній, як і у ветеринарній, вона використовується у вигляді високоефективних препаратів, а також носіїв цільової доставки лікарських засобів і фізіологічно активних речовин до вогнища патологічного процесу (Gel'pirina and Shvec, 2009; Ushkalov and Romanko, 2010; Borysevych et al., 2011; Underwood and van Eps, 2012; Etheridge, 2013).

Започатковані дослідження й у репродуктології (Borysevych and Borysevych, 2009; Barkalina et al., 2014). При цьому вивчення негативних факторів впливу дозволяє «розшифрувати» етіопатогенез патологій і відповідно розробити превентивні та терапевтичні заходи. Так, екологодефіцитобумовлені фактори сприяють виникненню дисбалансу у системі прооксидантно-антиоксидантного окислення та цитотоксичної гіпоксії, що обумовлює використання комбінова- них препаратів загальноклітинної дії, створених на основі нанобіоматеріалів (Koshevoi et al., 2016).

У зв'язку з цим мета нашої роботи полягала у розробці комплексних препаратів на основі нанобіоматеріалів і визначенні перспектив їх використання у репродукції овець та кіз.

\section{Матеріал і методи досліджень}

Досліди проводилися в умовах кафедри акушерства, гінекології і біотехнології розмноження тварин та навчально-практичного комплексу тваринництва i рослинництва Харківської державної зооветеринарної академії, відділу нанокристалічних матеріалів Інституту сцинтиляційних матеріалів НАН України (м. Харків) та центральної науково-дослідної лабораторії Національного фармацевтичного університету (м. Харків), а також фермерського господарства «Джерело» Дніпропетровського району Дніпропетровської області, господарствах приватного сектору зони обслуговування Сватівської районної державної лікарні ветеринарної медицини Луганської області та Вершинської ділянки ветеринарної медицини Куйбишевського району Запорізької області. 


\section{Результати та їх обговорення}

Запропоновані нами комплексні препарати «Кагадін+OV», «Каплаестрол+OV», «Карафест+OV» та «Карафанд $+\mathrm{OV} » ~ з$ вмістом нанобіоматеріалів розроблено на основі вітамінно-гормональних препаратів «Кагадін», «Каплаестрол», «Карафест» та «Карафанд», ефективність яких доведено у попередніх дослідженнях (Koshevoy et al., 2011).

Необхідність удосконалення препаратів обумовлена необхідністю надання їм антиоксидантних, антигіпоксичних та мембранопротекторних властивостей завдяки додаванню ортованадатів рідкісноземельних елементів і зокрема ортованадату гадолінію активованого європієм.

Нами апробовано препарат «Карафест+OVZn» у способі нормалізації структури i функції фетоплацентарного комплексу овець та підвищення потенціалу розвитку новонароджених ягнят.
Препарат «Карафест+OVZn» задавали перорально 3 кормом, щоденно за місяць до прогнозованого окоту (з 140 доби вагітності).

При обгрунтуванні дози препарату виходили з добової потреби тварин у складових препарату, яка для овець та кіз в останні 7-8 тижнів кітності становить (у розрахунку на тварину): каротин - 0,28-0,5 мг/кг маси тіла або 12-26 мг, фітоестрогени - 0,0175 мг/кг маси тіла або 0,61-1,22 мг, цинк - 1-1,08 мг/кг маси тіла або 54-70 мг.

Вміст речовин в 1 мл препарату «Карафест+OVZn» згідно ТУ складає: каротин - 10 мг $(1,2-$ 2,6 мл), фітоестрогени - 1 мг (0,6-1,2 мл), карбонат цинку -2 мг, OV $-0,00015$ мг.

Підсумкове дозування визначали за схемою 0,35-2,1 мл/гол., або 0,01-0,03 мл/кг живої маси / добу.

Вплив препарату «Карафест+OVZn» на показники гомеостазу у овець наведено у табл. 1 .

Табличя 1

Вплив препарату «Карафест+OVZn» на показники гомеостазу у овець

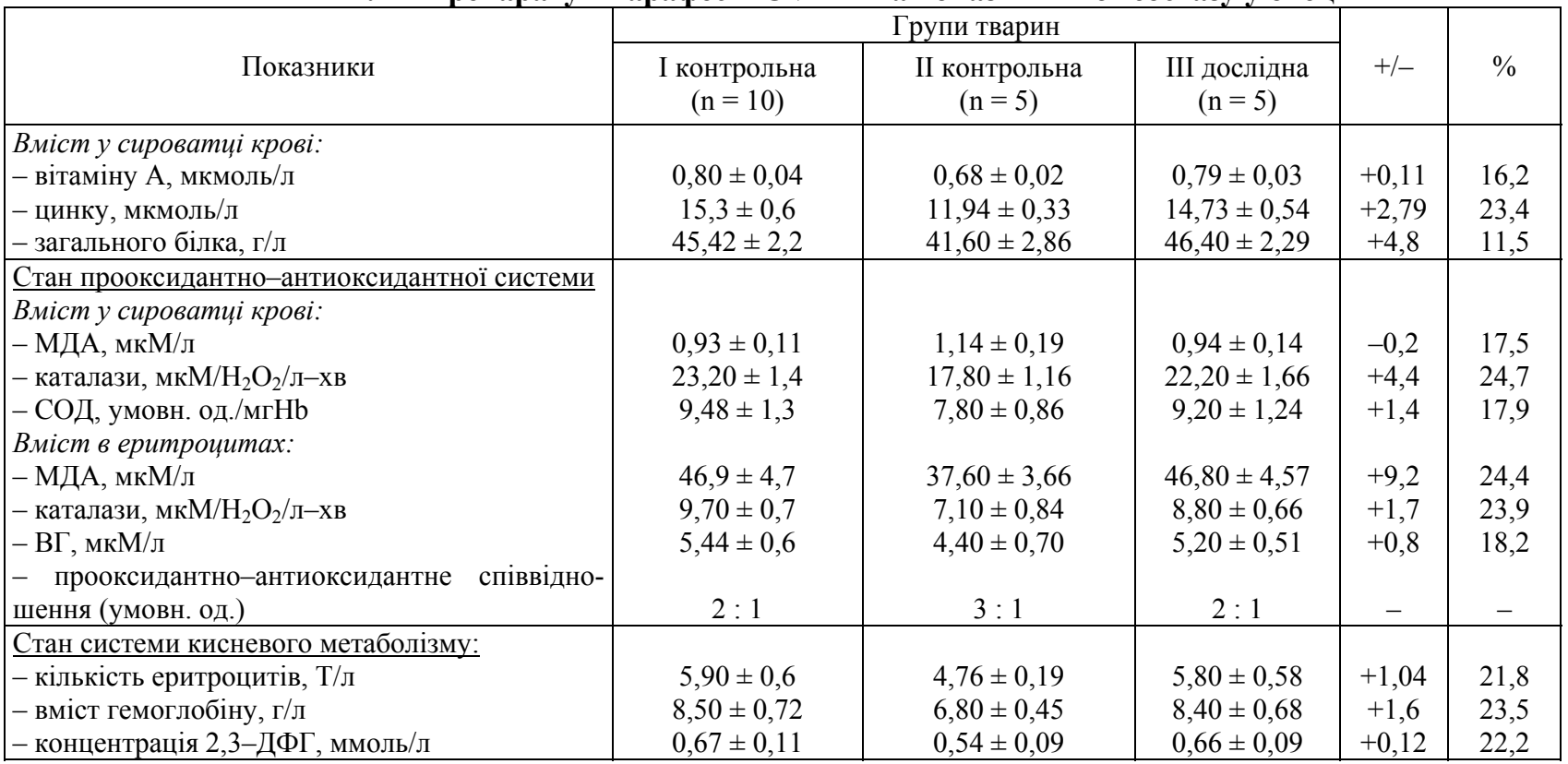

I контрольна - 120 доба вагітності; II контрольна - препарат не вводили, 145 доба вагітності; III дослідна - введення препарату, 145 доба вагітності

Як свідчать одержані дані, за використання препарату «Карафест+OVZn» збільшився вміст у сироватці крові: вітаміну А (на 16,2\%), цинку (на 23,4\%), загального білка (на 11,5\%), малонового діальдегіду (МДА) (на 17,5\%), каталази (на 24,7\%), супероксиддисмутази (СОД) (на 17,9\%); в еритроцитах: МДА (на 24,4\%), каталази (на 23,9\%) та відновленого глутатіону (ВГ) (на 18,2\%), а також вміст гесоглобіну (на 23,5\%), власне кількість еритроцитів (на 21,8\%), концентрація 2,3дифосфогліцерату (ДФГ) і нормалізувалася прооксидантно-антиоксидантне співвідношення.

\section{Висновки}

Встановлено позитивний вплив препарату «Карафест+OVZn» на показники гомеостазу у овець, зокрема нормалізацію вмісту у сироватці крові вітаміну А, цинку та загального білка; стан прооксидантноантиоксидантної системи за вмістом у сироватці крові МДА, каталази, СОД і в еритроцитах МДА, каталази, ВГ та прооксидантно-антиоксидантне співвідношення; стан системи кисневого метаболізму - кількість еритроцитів та гемоглобіну, концентрацію 2,3-ДФГ.

Перспективи подальших досліджень. Буде вивчено вплив на показники гомеостазу у овець та кіз інших розроблених нами комплексних препаратів на основі нанобіоматеріалів, а також визначено їх ефективність за репродуктивних патологій.

\section{Бібліографічні посилання}

Borysevych, V.B., Kaplunenko, V.H., Kosinov, M.V. (2011). Zdobutky i problemy nanotekhnolohii u veterynarnii praktytsi. Veterynarna praktyka. 10, 30- 
33 (in Ukrainian).

Ushkalov, V.O., Romanko, M.Ie. (2010). Vyznachennia bionebezpechnosti ta biosumisnosti nanochastynok metaliv dlia potreb veterynarnoi medytsyny. Veterynarna medytsyna Ukrainy. 6, 30-33 (in Ukrainian).

Gel'pirina, S.Je., Shvec, V.I. (2009). Sistemy dostavki lekarstvennyh veshhestv na osnove polimernyh nanochastic. Biotehnologija. 3, 8-23 (in Russian).

Glazko, V.I. (2010). Nanobiotehnologii - osnova novoj nauchno-tehnicheskoj revoljucii. Agro XXI. 4-6, 4548 (in Russian).

Koshevoi, V.P., Fedorenko, S.Ia., Naumenko, S.V. (2016). Kompleksni preparaty, stvoreni na osnovi nano-biomaterialiv ta yikh vykorystannia $u$ veterynarnii reproduktolohii (metodychni rekomendatsii). Dnipropetrovsk: vydavnytstvo «Porohy» (in Ukrainian).

Koshevoy, V.P., Sklyarov, P.M., Naumenko, S.V. (2011). Problemy vidtvorennya ovets' i kiz ta shlyakhy yikh vyrishennya: monohrafiya. Kharkiv; Dnipropetrovsk: Hamaliya (in Ukrainian).

Borysevych, V.B., Borysevych, B.V. (2009). Likuvannia koriv, khvorykh na mastyt, nanoakvakhelatamy koloidiv metaliv. Veterynarna medytsyna Ukrainy. 7, 20-22 (in Ukrainian).

Chekman, I.S. (2011). Nanonauka v Ukraini: do problemy doslidzhennia (istorychnyi aspekt i suchasnist). Suchasni problemy toksykolohii. 1/2, 16-21 (in Ukrainian).

Eifler, A.C., Thaxton, C.S. (2011). Nanoparticle therapeutics: FDA approval, clinical trials, regulatory pathways, and case study. Methods Mol. Biol. 726, 325-338.

Barkalina, N., Charalambous, C., Jones, C., Coward, K. (2014). Nanotechnology in reproductive medicine: emerging applications of nanomaterials. Nanomedicine. 10(5), 921-938.

Etheridge, M.L. (2013). The big picture on nanomedicine: the state of investigational and approved nanomedicine products. Nanomedicine: Nanotechnology, Biology and Medicine. 9(1), 1-4.

Underwood, C., van Eps, A.W. (2012). Nanomedicine and veterinary science: the reality and the practicality. Vet. J. 193(1), 12-23.

Стаття надійшла до редакиії 5.09.2016 